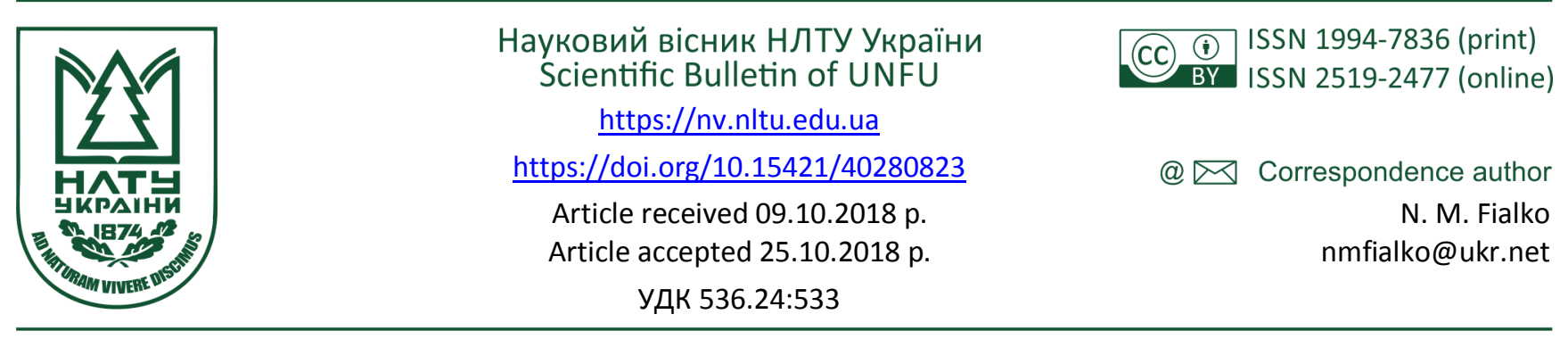

Н. М. Фиалко ${ }^{1}$, В. Г. Прокопов ${ }^{1, \text { С. А. Алёшко }}{ }^{,}$М. З. Абдулин ${ }^{1,2}$, К. В. Рокитько1, О. Е. Малецкая ${ }^{1}$, Е. И. Милко ${ }^{1}$ Н. Н. Ольховская ${ }^{1}$, А. Реграги ${ }^{1}$, А. А. Евтушенко1

${ }^{1}$ Институт технической теплофизики НАН Украины, г. Киев, Украина ${ }^{2}$ Национальный технический ун-тет Украины "Киевский политехнический институт им. Игоря Сикорского", г. Киев, Украина

\title{
КОМПЬЮТЕРНОЕ МОДЕЛИРОВАНИЕ ТЕЧЕНИЯ В МИКРОФАКЕЛЬНЫХ ГОРЕЛОЧНЫХ УСТРОЙСТВАХ С АСИММЕТРИЧНОЙ ПОДАЧЕЙ ТОПЛИВА
}

\begin{abstract}
Выявлены основные закономерности изотермического течения топлива и окислителя в микрофакельном горелочном устройстве с односторонней подачей топлива. Получены данные компьютерного моделирования с использованием подхода DES (Detached Eddy Simulation), представляющего собой комбинацию моделей RANS (Reynolds Averaged Navier-Stokes) и LES (Large Eddy Simulation) в разных областях пространства. Установлены эффекты влияния длины закрылка, расположенного на торцевой поверхности стабилизаторов пламени, на различные характеристики течения. Показано, что наличие закрылков приводит к существенному изменению вихревой структуры в следе за стабилизаторами. Оценено влияние длины закрылков на такие параметры течения, как протяженность зоны обратных токов в закормовой области стабилизаторов пламени, уровень среднеквадратичных пульсаций скорости в данных зонах и пр. Установлено, что с увеличением длины закрылков существенно возрастает протяженность зоны обратных токов за стабилизатором. Выявлено также, что чем короче закрылки, тем больше превышает их длину протяженность зоны обратных токов. Выполнен анализ пространственного распределения пульсаций скорости в рассматриваемом горелочном устройстве при наличии и отсутствии закрылков на торцевых поверхностях стабилизаторов пламени. Показано, что наиболее высокий уровень данных пульсаций наблюдается вблизи границы зоны обратных токов, удаленной от торца стабилизатора. Установлено, что уровень среднеквадратичных пульсаций скорости является наиболее высоким в условиях отсутствия закрылка и снижается при увеличении его длины.

Ключевые слова: стабилизаторы пламени; односторонняя подача топлива; CFD моделирование; зона обратных токов;
\end{abstract} закрылки.

Введение. Знание закономерностей протекания рабочих процессов в микрофакельных горелочных устройствах различного типа необходимо для их совершенствования, разработки новых модификаций и пр. В качестве инструмента исследования данных процессов в различных горелочных устройствах в последний период широко применяется компьютерное моделирование (Fialko et al., 2014 a; Ravi, 2014; Fialko et al., 2011 a; Bagheri et al., 2014; Fialko et al., 2010; Subramanian, 2010; Fialko et al., 2015; Lawal et al., 2010; Warnatz et al., 2003; Fialko et al., 2011b; Wan et al., 2012; Fialko et al., 2014b; Carlssona et al., 2014; Snegirev et al., 2015). Это связано, в частности с тем, что предсказания компьютерного моделирования становятся все более совершенными и, кроме того, позволяют получать детальную полевую информацию о различных характеристиках процесса.

В данном исследовании рассмотрено компьютерное моделирование изотермического течения топлива и окислителя в микрофакельных горелках с асимметричной подачей топлива. Рассмотрению подлежали горелочные устройства со струйным внедрением топлива в сносящий поток окислителя. При этом подача топлива осуществлялась лишь с одной из боковых поверхностей

Інформація про авторів:

Фиалко Наталія Михайлівна, д-р техн. наук, професор, член-кореспондент НАН України, завідувач відділу. Email: nmfialko@ukr.net; https://orcid.org/0000-0003-0116-7673

Прокопов Віктор Григорович, д-р техн. наук, професор, пров. наук. співробітник. Email: nmfialko@ukr.net; https://orcid.org/00000002-9026-8742

Алешко Сергій Олександрович, канд. техн. наук, пров. наук. співробітник. Email: s_aleshko@ukr.net; https://orcid.org/0000-00020430-7144

Абдулін Михайло Загретдинович, канд. техн. наук, ст. наук. співробітник; доцент, кафедра ТЕУ Т та АЕС. Email: mzabdulin@gmail.com

Рокитько Костянтин Володимирович, мол. наук. співробітник. Email: kr.kicenergetik@gmail.com

Малецька Ольга Євгенівна, канд. техн. наук, ст. наук. співробітник. Email: maletska@nas.gov.ua

Мілко Євген Іванович, ст. наук. співробітник. Email: milko_1963@ukr.net; https://orcid.org/0000-0002-4687-0998

Ольховська Ніна Миколаївна, наук. співробітник. Email: Ölchovska_Nina@ukr.net; https://orcid.org/0000-0001-7903-7225

Реграгі Абубакр, мол. наук. співробітник. Email: regrab@rambler.ru; https://orcid.org/0000-0001-5183-410X

Євтушенко Артем Олександрович, мол. наук. співробітник. Email: egda@ukr.net

Цитування за ДСтУ: Фиалко Н. М., Прокопов В. Г., Алёшко С. А. и др. Компьютерное моделирование течения в микрофакельных горелочных устройствах с асимметричной подачей топлива. Науковий вісник НЛтУ України. 2018, т. 28, № 8. С. $117-121$.

Citation APA: Fialko, N. M., Prokopov, V. G., Alioshko, S. A., et al. (2018). Computer simulation of flow in microjet burner devices with asymmetric supply of fuel. Scientific Bulletin of UNFU, 28(8), 117-121. https://doi.org/10.15421/40280823 
стабилизаторов пламени. Указанные горелочные устройства ориентированы на эксплуатацию в диапазоне изменения коэффициента избытка воздуха от 2,0 до 3,0. Такие условия характерны для горелок, устанавливаемых в промышленных печах, сушилках и пр.

Постановка задачи и методика проведения исследований. Модуль предлагаемого горелочного устройства состоит из двух плоских стабилизаторов, расположенных в канале на некотором расстоянии друг от друга (рис. 1). Струйная подача топлива в каждом из стабилизаторов осуществляется через систему круглых отверстий, расположенных на его боковой поверхности. Стабилизаторы снабжены плоскими закрылками, установленными на их торцевых поверхностях. Основные функции данных закрылков состоят, во-первых, в содействии образованию устойчивых зон обратных токов в закормовой области стабилизатора и, во-вторых, в формировании потока воздуха, призванного снизить температуру в центральной части зоны активного горения. Что касается указанного снижения, то оно является весьма важным в плане обеспечения высокой экологической эффективности рассматриваемого горелочного устройства. Следует также отметить, что поток холодного воздуха, текущий между двумя закрылками, служит целям их охлаждения.

Исследования проводились на основе CFD моделирования с использованием программного пакета FLUENT. При этом применялся метод DES (Detached Eddy Simulation - метод моделирования отсоединенных вихрей), представляющий собой гибридный подход, в котором осуществляется переключение моделей RANS (Reynolds Averaged Navier-Stokes - полуэмпирический метод, базирующийся на осредненных по Рейнольдсу стационарных уравнениях Навье-Стокса) и LES (Large Eddy Simulation - метод моделирования крупных вихрей) в разных областях пространства (Volkov \& Emelyanov, 2008).

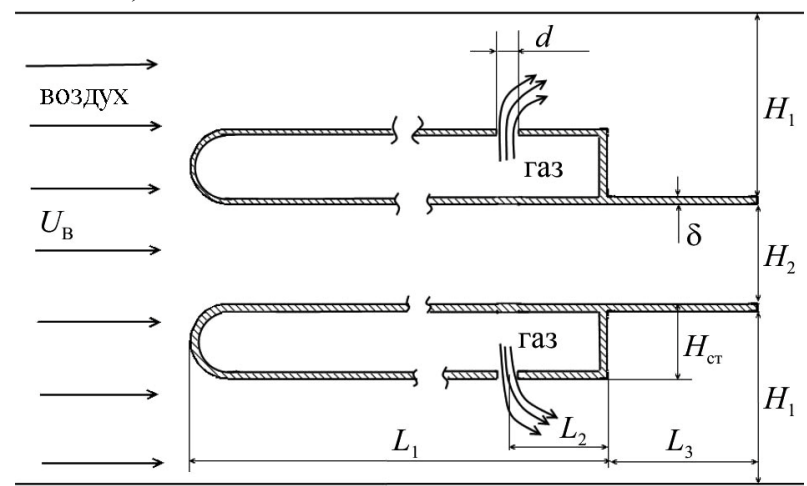

Рис. 1. Схема микрофакельного горелочного устройства стабилизаторного типа с односторонней подачей топлива: 1) плоский канал; 2) стабилизаторы пламени; 3) газоподающие отверстия; 4) закрылки

Приведенные ниже результаты компьютерного моделирования отвечают следующим исходным данным: $d=0,003 \mathrm{м} ; S / d=4,0 ; H_{C T}=0,015 \mathrm{~m} ; H_{1}=0,04 \mathrm{м} ;$ $H_{2}=0,02 \mathrm{M} ; \quad L_{1}=0,2 \mathrm{M} ; \quad L_{2}=0,02 \mathrm{M} ; \quad \delta=0,0015 \mathrm{M}$, $U_{B}=10,0 \mathrm{~m} / \mathrm{c}, \alpha=3,0$; рассматривались ситуации, отвечающие отсутствию закрылка $L_{3}=0$ и его наличию при $L_{3}=0,015 ; 0,03 ; 0,045$ и 0,06 м.

Анализ результатов исследований. При анализе результатов компьютерного моделирования особое внимание уделялось рассмотрению закономерностей влияния длины закрылка $L_{3}$ на характеристики течения топлива и окислителя. Как следует из данных, приведенных на рис. 2, картина течения в закормовой области стабилизатора с закрылками и без него является существенно различной. А именно, при отсутствии закрылка за стабилизатором наблюдается два основных вихря. В ситуации же с закрылком ярко выраженным является лишь один вихрь, центр которого смещается вниз по потоку с увеличением длины закрылка. При этом за торцом закрылка формируется вихрь небольших размеров, а в угловой зоне за стабилизатором вторичный вихрь.

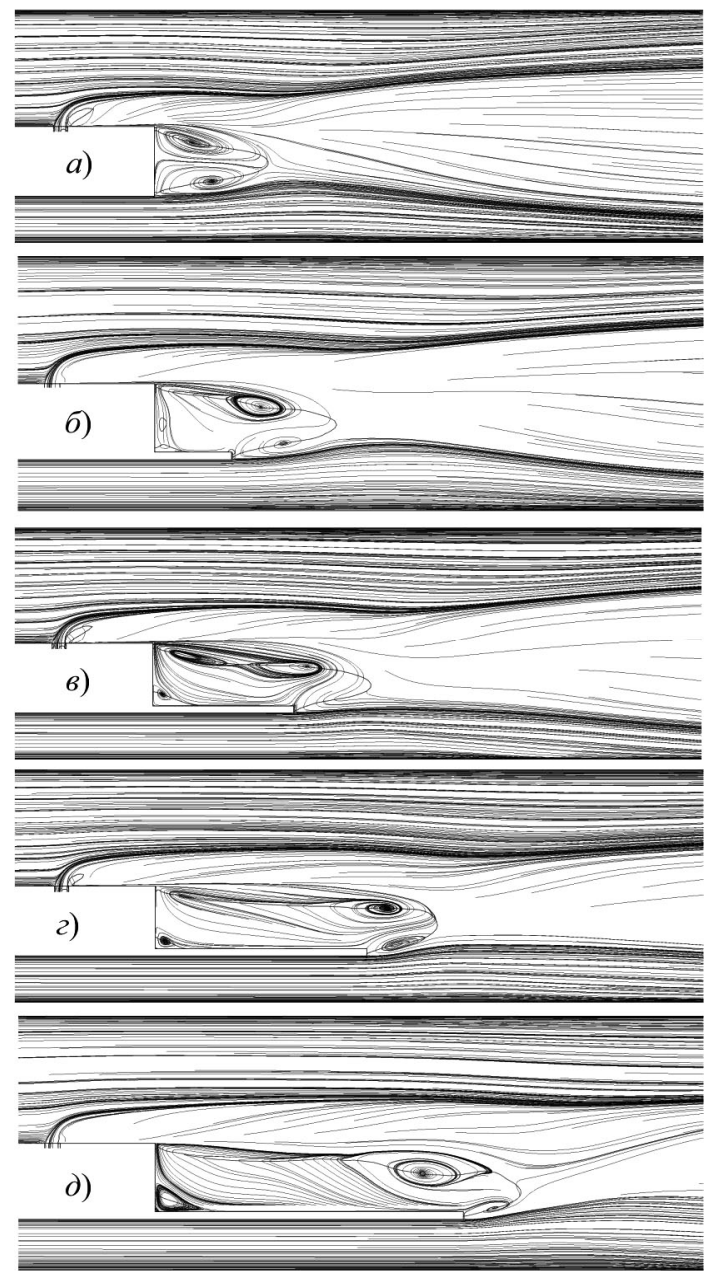

Рис. 2. Картина линий тока топлива и окислителя в продольном сечении стабилизатора, проходящем через ось газоподающих отверстий при различных значениях длины закрылка: a) $\mathrm{L}_{3}=0$; б) $\mathrm{L}_{3}=0,015 \mathrm{~m}$; в) $\mathrm{L}_{3}=0,03 \mathrm{м}$; г) $\mathrm{L}_{3}=0,045 \mathrm{M}$; д) $\mathrm{L}_{3}=0,06 \mathrm{~m}$

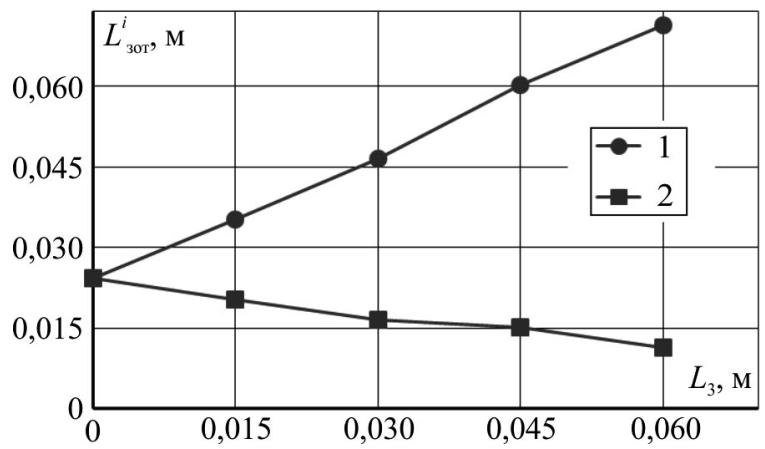

Рис. 3. Зависимость от длины закрылка $\mathrm{L}_{3}: 1$ ) протяженности зоны обратных токов $\left.L_{3 O T}^{1} ; 2\right)$ величины $L_{3 O T}^{2}$, на которую протяженность зоны обратных токов превышает длину закрылка

Что касается протяженности зоны обратных токов $L_{30 т}^{1}$ за стабилизатором, то она значительно увеличива- 
ется с ростом длины закрылка (рис. 3). Так, $L_{30 T}^{1}=$ 24,2 мм при $L_{3}=0$ и составляет 71,3 мм при $L_{3}=60$ мм. Следует отметить, что протяженность зоны обратных токов $L_{3 о т}^{1}$ превышает длину закрылка при всех значениях $L_{3}$. При этом данное превышение $L_{30 т}^{2}$ уменьшается с увеличением $L_{3}$.

Рис. 4 иллюстрирует распределение продольной составляющей вектора скорости в закормовой области стабилизатора вдоль его оси при разных значениях длины закрылка. Как видно, при отсутствии закрылка максимальное по абсолютной величине значение скорости $U_{x}^{\max }$ в зоне обратных токов имеет место примерно посередине ее длины. В случае же стабилизатора с закрылком местоположение скорости $U_{x}^{\max }$ смещается вниз по течению ближе к границе зоны обратных токов. При этом данное смещение оказывается тем более значительным, чем длиннее закрылок. Обращает на себя внимание также тот факт, что при наличии закрылка непосредственно вблизи стабилизатора наблюдается область с пониженными по абсолютной величине значениями скорости $U_{x}$. Причем протяженность данных областей возрастает с увеличением длины закрылка.

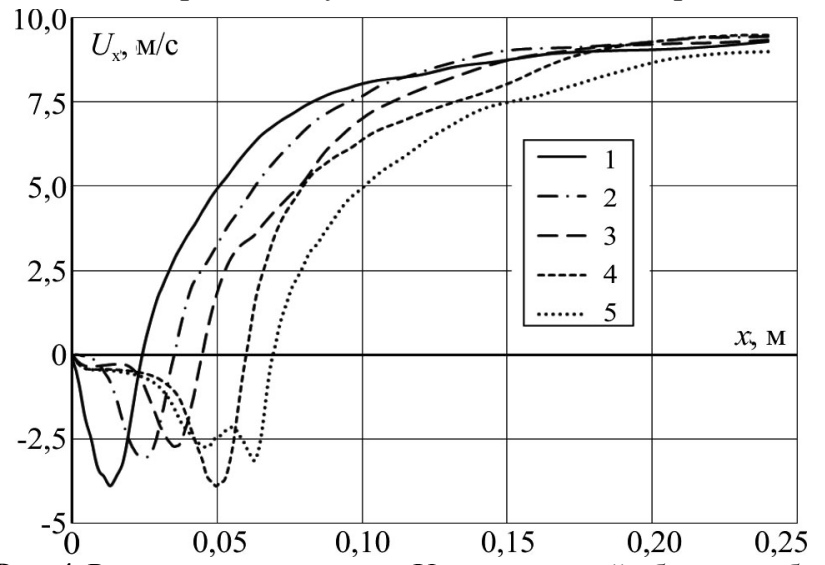

Рис. 4. Распределение скорости $U_{\mathrm{x}}$ в закормовой области стабилизатора вдоль его продольной оси при различных значениях длины закрылка: $1-\mathrm{L}_{3}=0 ; 2-\mathrm{L}_{3}=0,015 \mathrm{~m} ; 3-\mathrm{L}_{3}=0,03 \mathrm{~m} ; 4-$ $\mathrm{L}_{3}=0,045 \mathrm{~m} ; 5-\mathrm{L}_{3}=0,06 \mathrm{M}$

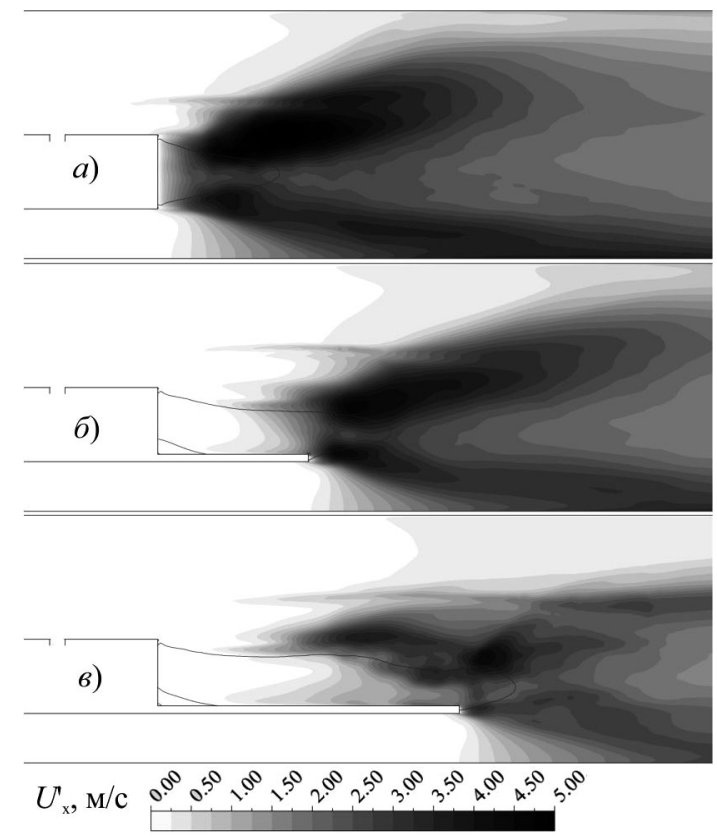

Рис. 5. Поля среднеквадратичных пульсаций скорости $U_{x}^{\prime}$ в продольном сечении стабилизатора, проходящем через ось га- зоподающих отверстий, при различных значениях длины закрылка: а) $\mathrm{L}_{3}=0$; б) $\mathrm{L}_{3}=0,03$ м; в) $\mathrm{L}_{3}=0,06 \mathrm{м}$

Анализ полей среднеквадратичных пульсаций скорости $U_{x}^{\prime}$ для рассматриваемых физических ситуаций свидетельствует о том, что наибольшие значения данных пульсаций имеют место в закормовой области стабилизатора (рис. 5). При этом подобласти, отвечающие указанным наибольшим значениям, вытянуты вниз по потоку и располагаются вблизи, удаленной от торца стабилизатора, границы циркуляционной зоны. Что касается уровня среднеквадратичных пульсаций скорости $U_{x}^{\prime}$, то в целом он оказывается наиболее высоким при отсутствии закрылка и уменьшается с увеличением его длины.

Выводы. На основе компьютерного моделирования выполнены исследования закономерностей изотермического течения топлива и окислителя в микрофакельном горелочном устройстве с асимметричной струйной подачей топлива в сносящий поток окислителя. Получены данные об эффектах влияния длины закрылков, расположенных на торцевых поверхностях стабилизаторов, на различные характеристики течения. Показано, что наличие данных закрылков приводит к существенному изменению картины течения в закормовой области стабилизатора, обуславливая формирование более сложных вихревых структур. Установлено, что с увеличением длины закрылков значительно возрастает протяженность зоны обратных токов за стабилизатором и изменяется характер распределения скоростей в данной зоне. Показано, что максимальные пульсации продольной составляющей скорости в зонах обратных токов имеют место в случае стабилизаторов без закрылков. При увеличении длины закрылков уровень данных пульсаций снижается.

Перспективы дальнейших исследований состоят, прежде всего, в анализе структуры течения в рассматриваемых горелочных устройствах в условиях реагирующих потоков. Кроме того, значительный интерес представляет изучение закономерностей смесеобразования топлива и окислителя, а также выгорания топлива и формирования полей температуры в зоне горения.

\section{Перелік використаних джерел}

Bagheri, G., Hosseini, S. E., \& Wahid, M. A. (2014). Effects of bluff body shape on the flame stability in premixed micro-combustion of hydrogen-air mixture. Applied Thermal Engineering, 67, 26-27. https://doi.org/10.1016/j.applthermaleng.2014.03.040

Carlssona, H., Nordströmb, E., Bohlinb, A., Peterssonb, P., Wua, Y., Collinb, R., Aldénb, M., Bengtssonb, P.-E., \& Baia, X.-S. (2014). Large eddy simulations and rotational CARS/PIV/PLIF measurements of a lean premixed low swirl stabilized flame. Combustion and Flame, 161(10), 2539-2551. https://doi.org/10.1016/j.combustflame.2014.03.017

Fialko, N. M., Butovskii, L. S., Prokopov, V. G., Sherenkovskii, Ju. V., Meranova, N. O, Aleshko, S. A., \& Polozenko, N. P. (2011). Kompiuternoe modelirovanie protsessa smeseobrazovaniia $\mathrm{v}$ gorelochnykh ustroistvakh stabilizatornogo tipa s podachei gaza vnedreniem v snosiashchii potok vozdukha. [Computer simulation of the process of mixture formation in burner devices of the stabilizer type with gas introduction of gas into the blowing air flow]. Industrial Heat Engineering, 33(1), 51-56. [In Russian].

Fialko, N. M., Prokopov, V. G., Butovskii, L. S., Sherenkovskii, Ju. V., Aleshko, S. A., Meranova, N. O., \& Polozenko, N. P. (2011). Osobennosti techeniia topliva i okislitelia pri eshelonirovannom raspolozhenii stabilizatorov plameni. [Peculiarities of the flow of fuel 
and oxidizer at the layered arrangement of flame stabilizers]. Industrial Heat Engineering, 33(2), 59-64. [In Russian].

Fialko, N. M., Prokopov, V. G., Butovskii, L. S., Sherenkovskii, Ju. V., Meranova, N. O., Aleshko, S. A., Kokhanenko, P. S., \& Polozenko, N. P. (2010). Modelirovanie struktury techeniia izotermicheskogo potoka $\mathrm{v}$ eshelonirovannoi reshetke ploskikh stabilizatorov plameni. [Modeling of the structure of an isothermal flow in an echeloned lattice of flat flame stabilizers]. Industrial Heat Engineering, 32(6), 28-36. [In Russian].

Fialko, N. M., Sherenkovskii, Ju. V, Prokopov, V. G., Polozenko, N. P., Meranova, N. O., Aleshko, S. A., Ivanenko, G. V., Yurchuk, V. L., Milko, E. I., \& Olkhovskaia, N. N. (2015). Modelirovanie struktury techeniia $\mathrm{v}$ eshelonirovannykh reshetkakh stabilizatorov pri varirovanii shaga ikh smeshcheniia. [Modeling of the flow structure in echeloned grids of stabilizers by varying their displacement step] (Vol. 2). Eastern-European Journal of Enterprise Technologies, 8(74), 29-34. https://doi.org/10.15587/1729-4061.2015.39193

Fialko, N. M., Sherenkovskii, Ju. V., Mayson, N. V., Meranova, N. O., Abdulin, M. Z., Butovskii, L. S., Polozenko, N. P., Klishch, A. V., Stryzheus, S. N., \& Timoshchenko, A. B. (2014). Matematicheskoe modelirovanie protsessov techenija i smeseobrazovanija $\mathrm{v}$ tsilindricheskom stabilizatornom gorelochnom ustrojstve. [Mathematical modeling of the processes of flow and mixture formation in a cylindrical stabilizer burner device]. (Vol. 3). Eastern- European Journal of Enterprise Technologies, 8(69), 40-44. https://doi.org/10.15587/1729-4061.2014.24895

Fialko, N. M., Sherenkovskii, Ju. V., Mayson, N. V., Meranova, N. O., Butovskii, L. S., Abdulin, M. Z., Polozenko, N. P., Klishch, A. V., Strizheus, S. N., \& Timoshchenko, A. B. (2014). Intensifikatsiia protsessov perenosa $\mathrm{v}$ gorelochnom ustroistve $\mathrm{s}$ tcilindricheskim stabilizatorom plameni. [The intensification of transfer processes within a burner with a cylindrical flame holder]. Scientific Bulletin of UNFU, 24(5), 136-142. [In Russian].

Н. М. Фіалко1, В. Г. Прокопов1, С. О. Альошко1, М. З. Абдулін ${ }^{1,2}$, К. В. Рокитько1, о. Є. Малецька', Є. І. Мілко1, Н. М. Ольховська', А. Реграгі', А. о. Євтушенко1

${ }^{1}$ Інститут технічної теплофізики НАН Украӥни, м. Київ, Украӥна ${ }^{2}$ Національний технічний університет Украӥни "Київський політехнічний інститут ім. Ігоря Сікорського", м. Київ, Украӥна
Lawal, M. S., Fairweather, M., Ingham, D. B., Ma, L., Pourkashanian, M., \& Williams, A. (2010). Numerical Study of Emission Characteristics of a Jet Flame in Cross-Flow. Combustion Science and Technology, 182(10), 1491-1510. https://doi.org/10.1080/00102202.2010.496379

Ravi, D. (2014). Large Eddy Simulation of Triangular Bluff-Body Stabilized Flames in Partially Premixed Condition. Middle-East Journal of Scientific Research, 20(10), 1234-1238. https://doi.org/10.5829/idosi.mejsr.2014.20.10.114098

Snegirev, A., Kokovina, E., \& Tsoy, A. (2015). Coupled simulations of turbulent flame and pyrolysis of combustible material. Proceedings of the European Combustion Meeting, Paper P4-16, March 30 - April 2. Budapest, Hungary.

Subramanian, V., Domingo, P., \& Vervisch, L. (2010). Large eddy simulation of forced ignition of an annular bluff-body burner. Combustion and Flame, 157, 579-601. https://doi.org/10.1016/j.combustflame.2009.09.014

Volkov, K. N., \& Emelyanov, V. N. (2008). Modelirovanie krupnykh vikhrei $v$ raschetakh turbulentnykh techenii. [Modeling of large eddies in calculations of turbulent flows]. Moscow: FIZMATLIT. [In Russian].

Wan, J., Fan, A., Maruta, K., Yao, H., \& Liu, W. (2012). Experimental and numerical investigation on combustion characteristics of premixed hydrogen/air flame in a micro-combustor with a bluff body. International Journal Hydrogen Energy, 37, 19190-19197. https://doi.org/10.1016/j.ijhydene.2012.09.154

Warnatz, J., Maas, U., \& Dibble, R. W. (2003). Goreniye. Fizicheskie $i$ khimicheskie aspekty, modelirovanie, eksperimenty, obrazovanie zagriazniaiushchikh veshchestv. [Combustion. Physical and chemical fundamentals, modeling and simulations, experiments, pollutant formation]. Moscow: Fizmatlit. [In Russian].

\section{КОМП'ЮТЕРНЕ МОДЕЛЮВАННЯ ТЕЧІЇ В МІКРОФАКЕЛЬНИХ ПАЛЬНИКОВИХ ПРИСТРОЯХ З АСИМЕТРИЧНОЮ ПОДАЧЕЮ ПАЛИВА}

Виявлено основні закономірності ізотермічної течії палива і окиснювача в мікрофакельному пальниковому пристрої 3 односторонньою подачею палива. Отримано дані комп'ютерного моделювання з використанням підходу DES (Detached Eddy Simulation), що представляє собою комбінацію моделей RANS (Reynolds Averaged Navier-Stokes) i LES (Large Eddy Simulation) в різних областях простору. Встановлено ефекти впливу довжини закрилка, розташованого на торцевій поверхні стабілізаторів полум'я, на різні характеристики течії. Показано, що наявність закрилків призводить до істотної зміни вихрової структури в сліді за стабілізаторами. Оцінено вплив довжини закрилків на такі параметри течії, як протяжність зони зворотних токів у закормовій області стабілізаторів полум'я, рівень середньоквадратичних пульсацій швидкості в цих зонах тощо. Встановлено, що зі збільшенням довжини закрилків істотно зростає протяжність зони зворотних токів за стабілізатором. Виявлено також, що чим коротші закрилки, тим більше перевищує їх довжину протяжність зони зворотних токів. Виконано аналіз просторового розподілу пульсацій швидкості в цьому пальниковому пристрої за наявності та відсутності закрилків на торцевих поверхнях стабілізаторів полум'я. Показано, що найвищий рівень цих пульсацій спостерігається поблизу границі зони зворотних токів, віддаленої від торця стабілізатора. Встановлено, що рівень середньоквадратичних пульсацій швидкості $є$ найвищим в умовах відсутності закрилка і знижується зі збільшенням його довжини.

Ключові слова: стабілізатори полум'я; одностороння подача палива; CFD моделювання; зона зворотних токів; закрилки.

N. M. Fialko', V. G. Prokopov' ${ }^{1}$, S. A. Alioshko', M. Z. Abdulin ${ }^{1,2}$, K. V. Rokitko', O. E. Maletska ${ }^{1}$, E. I. Milko' ${ }^{1}$, N. N. Olkhovska ${ }^{1}$, A. Regragi ${ }^{1}$, A. A. Evtushenko ${ }^{1}$

${ }^{1}$ Institute of Engineering Thermophysics, NAS of Ukraine, Kyiv, Ukraine ${ }^{2}$ National Technical University of Ukraine "Igor Sikorsky Kyiv Polytechnic Institute", Kyiv, Ukraine

\section{COMPUTER SIMULATION OF FLOW IN MICROJET BURNER DEVICES WITH ASYMMETRIC SUPPLY OF FUEL}

This article is devoted to the mathematical modeling of the isothermal flow in microjet burner devices with asymmetric jet supply of fuel by the introduction into the flow of an oxidizer. The studies were conducted on the basis of CFD modeling using the Ansys Fluent software. The Detached Eddy Simulation (DES) method, which is a hybrid approach, was used, in which Reynolds Averaged Navier-Stokes (RANS) and Large Eddy Simulation (LES) models are switched in different subregions of the computational domain. Particular attention in this article is paid to the comparative analysis of the flow characteristics in the presence and absence of flaps installed on the end surface of the flame stabilizers. According to the results of computer predictions, it is shown that, the flow pattern in the burner device changes significantly in the presence of flaps. These changes are also defined to be associated primarily with 
the formation of vortex structures in the region located behind the stern of the flame stabilizers. The analysis of the effect of flap length on different flow characteristics was performed. An increase in the flap length is shown to lead to a significant increase in the length of the reverse flow zone behind the flame stabilizer. This length is proved to exceed the flap length the greater, the shorter the flap. The features of the velocities distribution within the zone of reverse flows for various values of the flap length are revealed. The analysis of the fields of root-mean-square pulsations of velocity in the considered physical situations was carried out. The subregions corresponding to the highest levels of these pulsations are defined to be located near the boundary of the zone of reverse currents remote from the end of the flame stabilizers. The highest level of these velocity pulsations is revealed to meet the conditions for the absence of flaps on flame stabilizers. Some prospects for further research consist primarily in the analysis of the flow structure in the burner devices considering the conditions of reacting flows. Moreover, the study of the regularities of the mixing of fuel and oxidant is of considerable interest, as well as the burning out of fuel and the formation of temperature fields in the combustion zone.

Keywords: flame stabilizers; jet supply of fuel; CFD simulation; reverse flow zone; flaps. 